\title{
Penurunan Kecemasan Kehamilan melalui Kelas Prenatal
}

\section{Decrease Pregnancy Anxiety with Prenatal Class}

\section{Arum Meiranny* \\ RR Catur Leny Wulandari \\ Alfiah Rahmawati \\ Muliatul Jannah \\ Department of Midwifery, Universitas Islam Sultan Agung, Semarang, Central Java, Indonesia \\ *email: arummeiranny@unissula.ac.id}

Kata Kunci

Kecemasan

Kehamilan

Kelas Prenatal

Keywords:

Anxiety

Pregnancy

Prenatal Class

Received: September 2019

Accepted: November 2019

Published: December 2019

\begin{abstract}
Abstrak
Kecemasan ibu hamil saat menghadapi proses kehamilan berbeda-beda. Jumlah ibu hamil yang memiliki umur kehamilan lebih dari 20 minggu di Puskesmas Bangetayu adalah 30 orang. Hampir $60 \%$ ibu hamil tidak rutin melakukan ANC dan sebagian besar ibu khawatir dirujuk ke RS saat persalinan, sehingga banyak yang merasakan cemas. Padahal, komplikasi tersebut pada dasarnya dapat dideteksi lebih dini jika ibu rutin dan patuh melakukan ANC. Solusi permasalahan ini bertujuan untuk mengurangi kecemasan dan mengoptimalkan motivasi ibu hamil untuk mengembangkan suatu program guna meningkatkan pengetahuan ibu hamil dan kepatuhan ibu hamil melakukan ANC dengan pendekatan diskusi sesama ibu hamil melalui pembentukan Kelas Prenatal. Pelaksanaan kegiatan dengan penerapan IPTEK yang dilakukan dua kali, yaitu tanggal 29 Agustus 2018 dan 26 September 2018 dengan sasaran ibu hamil di Puskesmas Bangetayu Kota Semarang. Bentuk transfer IPTEK diawali dengan pre test dan di akhiri dengan post test, edukasi disampaikan dengan metode yang mudah dipahami yaitu memberikan materi tentang: nutrisi ibu hamil, ketidaknyamanan ibu hamil, tanda bahaya ibu hamil, persiapan persalinan, persiapan menyusui, KB pasca persalinan, dan senam hamil. Semua peserta juga langsung melakukan senam hamil pada saat pelaksanaan sesuai instruksi dari tim pengusul. Selain itu, sesama peserta juga saling berdiskusi dan bertukar pengalaman tentang kehamilannya. Tingkat kecemasan ibu hamil dari hasil pre test dan post test menurun sebesar 6,85\%, peserta merasa lebih tenang dalam menghadapi proses kehamilannya, terutama dalam menghadapi persalinan. Hal terpenting kegiatan ini adalah ibu akan mengajarkan kepada ibu hamil lainnya.
\end{abstract}

\begin{abstract}
Pregnant mothers' anxiety when facing the pregnancy process is different. Nearly $60 \%$ of pregnant women do not routinely perform ANC and most women worry about being referred to the hospital during labor, so many feel anxious. In fact, these complications can basically be detected earlier if the mother routinely and obediently performs an ANC. The solution to this problem is to reduce anxiety and optimize the motivation of pregnant women to develop a program to increase the knowledge of pregnant women and the compliance of pregnant women to carry out ANC with a discussion approach among pregnant women through the formation of Prenatal Classes. The form of science and technology transfer begins with a pre-test and ends with a posttest, education is delivered with an easy-to-understand method that provides material about: nutrition for pregnant women, discomfort of pregnant women, danger signs for pregnant women, preparation for delivery, preparation for breastfeeding, postpartum birth control, and pregnancy exercise. All participants also immediately did pregnancy exercise at the time of implementation according to instructions from the proposing team. In addition, fellow participants also discussed and exchanged experiences about their pregnancy. The anxiety level of pregnant women from the pre-test and posttest results decreased by $6.85 \%$, participants felt calmer in dealing with the process of pregnancy, especially in the face of childbirth. The most important thing for this activity is that the mother will teach other pregnant women.
\end{abstract}




\section{PENDAHULUAN}

Kehamilan merupakan suatu proses pembuahan dalam rangka melanjutkan keturunan yang terjadi secara alami, menghasilkan janin yang tumbuh di dalam rahim ibu. Lamanya hamil adalah 280 hari dihitung dari hari pertama haid terakhir (HPHT) (Syafrudin, 2011). Kehamilan merupakan pengalaman yang sangat mengesankan bagi seorang perempuan dan peristiwa kehidupan yang besar maknanya. Kondisi ini merupakan masa meningkatnya kewaspadaan dan terjadi perubahan besar (Astuti et al., 2000).

Kehamilan dan persalinan merupakan suatu hal yang alami akan tetapi bukan berarti tanpa resiko. Kehamilan dan persalinan memberikan kontribusi terhadapnya banyaknya Angka Kematian Ibu (AKI) dan Angka Kematian Bayi (AKB) (Machmudah et al., 2018). Upaya untuk menurunkan AKI dapat dilakukan dengan upaya preventif dan promotif dengan melibatkan semua unsur dalam masyarakat dan dilakukan secara terus menerus dan konsisten. Strategi yang dapat dilakukan adalah dengan menyelenggarakan kelas prenatal (Schott, 2008). Kelas prenatal merupakan salah satu sarana yang tepat untuk belajar tentang kesehatan bagi ibu hamil, dalam bentuk tatap muka dalam kelompok yang bertujuan untuk meningkatkan pengetahuan dan keterampilan (Sasnitiari \& Puspitasari, 2017). Melalui kelas ibu hamil, penyuluhan dan pendidikan kesehatan dapat dilakukan secara komprehensif, berkesinambungan, dan terencana. Hal tersebut bermanfaat guna mengurangi kelemahankelemahan penyuluhan tentang KIA saat ini, yang notebene masih banyak yang dilakukan melalui konsultasi perorangan atau kasus per kasus yang diberikan bidan atau petugas lain pada saat pemeriksaan antenatal atau pada kegiatan posyandu (Winarni, 2014).

Kelas prenatal bertujuan untuk meningkatkan pemahaman, sikap dan perilaku ibu hamil tentang kehamilan, apa saja yang perlu dilakukan ibu hamil dan pengaturan gizi termasuk pemberian tablet tambah darah untuk penanggulangan anemia, perawatan kehamilan, tanda bahaya kehamilan, tanda-tanda persalinan, tanda bahaya persalinan dan proses persalinan. Hal tersebut menunjukkan bahwa manfaat dari mengikuti kelas ibu hamil yaitu kehamilan menjadi sehat bagi ibu danjanin (Andriani et al., 2016). Kehamilan yang tidak terkontrol dan tidak mengetahui tanda bahaya kehamilan dapat menyebabkan kesejahteraan ibu dan janin menurun (Schott, 2008).

Salah satu cara yang dilakukan oleh Pemerintah Kota Semarang adalah dengan pencanangan Program Perencanaan Persalinan dan Pencegahan Komplikasi (P4K), yang terdiri dari empat langkah yaitu:

1. Pencatatan data kehamilan dengan menempelkan stiker tanda di setiap rumah ibu hamil sehingga masyarakat dapat memantau kondisi kesehatan ibu hamil.

2. Melakukan program donor darah sebagai upaya antisipasi terhadap adanya kasus perdarahan selama periode perinatal yang di koordinir oleh bidan desa.

3. Merencanakan dan menyiapkan alat transportasi jika ibu hamil memerlukan rujukan.

4. Perencanaan masalah pembiayaan dan menginformasikan ketersediaan bantuan dana jika dibutuhkan.

Namun program tersebut belum mendapat respon positif dari masyarakat, sehingga program ini dianggap tidak memberi kontribusi terhadap penurunan AKI di Kota Semarang. Hal ini disebabkan karena rendahnya pengetahuan dan kesadaran masyarakat tentang pentingnya program tersebut dan ketidakpatuhan ibu hamil melakukan antenatal care (ANC) karena alasan bekerja di luar rumah (Dwijayanti, 2013).

Berdasarkan survey pendahuluan kepada bidan koordinator Puskesmas Bangetayu didapatkan data bahwa jumlah ibu hamil sebanyak 30 ibu hamil yang 
memiliki umur kehamilan lebih dari 20 minggu. Dan di tahun sebelumnya, hampir $60 \%$ ibu hamil tidak secara rutin melakukan ANC dengan alasan bekerja dan sebagian besar ibu melahirkan dirujuk ke RS dengan indikasi medis seperti ibu hamil dengan komplikasi hipertensi, ibu hamil dengan anemia dan kesulitan dalam persalinan (distosia). Komplikasi kehamilan dan persalinan tersebut pada dasarnya dapat dideteksi lebih dini jika ibu rutin dan patuh melakukan ANC (Siwi \& Palupi, 2018).

Ketidakpatuhan untuk melakukan ANC selain karena alasan ibu bekerja juga didukung oleh kurangnya pengetahuan ibu hamil akan pentingnya melakukan ANC sebagai upaya untuk deteksi dini kondisi kesehatan ibu hamil dan janinnya (Ira et al., 2016). Selain itu, Puskesmas Bangetayu sudah menjalankan program pemerintah berupa Continuity of Care (COC), sehingga melihat potensi dan kondisi ibu hamil di Wilayah Kerja Puskesmas Bangetayu dan untuk mendukung program COC tersebut. Agar ibu memiliki kehamilan yang berkualitas, persalinan aman, serta bayi lahir dalam keadaan sehat, maka perlu dikembangkan suatu program yang bertujuan untuk meningkatkan pengetahuan ibu hamil dan meningkatkan kepatuhan ibu hamil untuk melakukan ANC dengan pendekatan peer group melalui pembentukan Kelas Prenatal (Mbuagbaw et al., 2015).

Wilayah Kerja Puskesmas Bangetayu Kota Semarang terdiri dari 6 kelurahan, saat ini ibu hamil yang umur kehamilannya diatas 20 minggu sebanyak 30 orang. Permasalahan mitra yang menjadi fokus pengusul adalah tingginya kecemasan ibu hamil yang diakibatkan oleh rendahnya pengetahuan dan kesadaran masyarakat tentang pentingnya program $\mathrm{P} 4 \mathrm{~K}$ serta ketidakpatuhan ibu hamil melakukan ANC. Adanya permasalahan mitra yang didapatkan oleh tim pengusul, maka pengusul menawarkan solusi berupa pembentukan peer grup dalam kelas prenatal. Melalui peer grup dalam kelas prenatal, ibu hamil diharapkan mau dan mampu saling berdiskusi tentang kondisi kehamilannya, sehingga dapat menambah wawasan dan pengetahuan tentang kehamilannya, dan akhirnya kecemasan yang dirasakan dapat berkurang. Target luaran yang diharapkan adalah terbentuknya peer grup dalam kelas prenatal dan keberlanjutan kegiatan kelas prenatal, sehingga semua informasi dan transfer IPTEK dapat berlangsung.

\section{METODOLOGI}

Pelaksanaan pengabdian masyarakat ini dilaksanakan di wilayah kerja Puskesmas Bangetayu Kota Semarang dengan pengusul yang berstatus sebagai fasilitator kelas prenatal. Kelas prenatal dilakukan dua kali dengan mengumpulkan ibu hamil di Bidan Praktik Mandiri Karangroto Kota Semarang. Sebelum pelaksanaan kegiatan, ibu hamil diberikan beberapa pertanyaan tertulis, yang digunakan sebagai pretest.

Transfer IPTEK yang diberikan yaitu dengan memberikan beberapa materi yang terkait dengan proses kehamilan, persalinan, nifas, dan bayi, serta praktik senam hamil. Selain itu, pengusul membuka forum diskusi dengan sesama ibu hamil, sehingga terbentuklah peer group discussion. Ilmu pengetahuan yang disampaikan dalam kelas prenatal antara lain sebagai berikut: nutrisi ibu hamil, ketidaknyamanan ibu hamil, tanda bahaya ibu hamil, persiapan persalinan, persiapan menyusui, dan KB pasca persalinan.

Setelah penyampaian materi, ibu hamil akan diajarkan tentang senam hamil, dan langsung mendemonstrasikannya, dan pengusul berstatus sebagai instruksur senam hamil. Pada saat pelaksanaan senam hamil, diputarkan musik klasik, sehingga ibu hamil akan merasakan ketenangan. Setelah selesai 
pelaksanaan, dilakukan posttest untuk mengukur keberhasilan kegiatan kelas prenatal.

\section{HASIL DAN PEMBAHASAN}

Bertambahnya pengetahuan tentang proses kehamilannya diharapkan mampu mengajarkan kepada masyarakat secara langsung dan berkelanjutan bagi setiap ibu hamil untuk mengurangi kecemasan dan meningkatkan motivasi internalnya untuk patuh melakukan ANC sebagai upaya deteksi dini pencegahan komplikasi. Untuk memudahkan dalam mentransfer IPTEK, setiap ibu juga dibekali dengan leaflet dan buku KIA.

Pelaksanaan kegiatan yang dilaksanakan dalam waktu yang singkat sangatlah terbatas. Kegiatan kelas prenatal juga harus menunggu ibu setelah pulang bekerja, sehingga waktu mulai pelaksanaan sedikit mundur dari yang direncanakan. Supaya keberlanjutan transfer IPTEK tetap berjalan, ibu hamil akan menyampaikan materi-materi dan mengajarkan cara yang telah disampaikan kepada ibu-ibu hamil yang lainnya di wilayah Puskesmas Bangetayu Kota Semarang dan juga di kantor tempat mereka bekerja.

Dampak langsung dari kegiatan ini adalah kecemasan ibu hamil dapat berkurang. Ibu hamil yang turut andil dalam kegiatan ini dapat menyampaikan secara kontinyu dan berkelanjutan kepada ibu lainnya. Hasil post test kecemasan ibu hamil mengalami penurunan sebesar 6,85\%, serta ibu dapat mempraktikkan senam hamil dan pengurangan ketidaknyamanan kehamilan lainnya. Penyampaian IPTEK yang diberikan secara terus-menerus kepada masyarakat supaya masyarakat sadar akan pentingnya mengetahui proses kehamilan dan tepat dalam menghadapi permasalahan selama kehamilan.

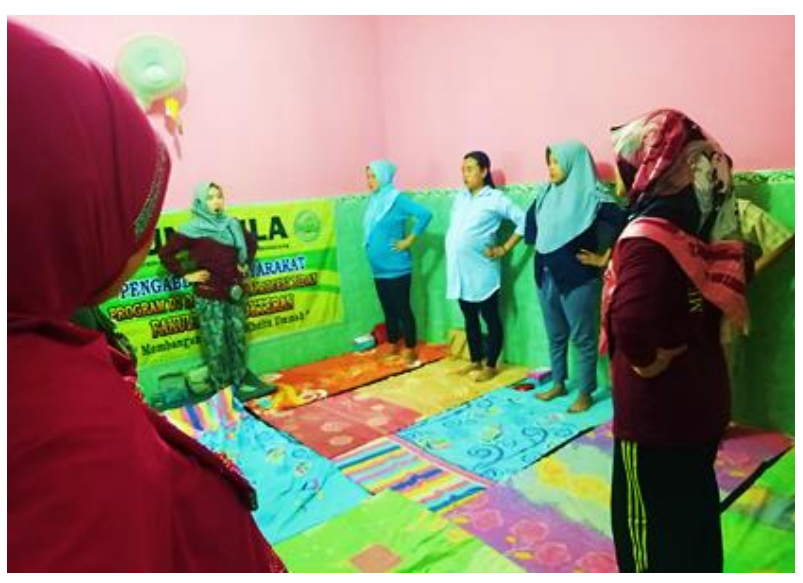

Gambar 1. Pelaksanaan Senam Hamil saat Pelaksanaan Kelas Prenatal

Dari sejumlah penelitian medis terakhir menyarankan bahwa ibu hamil harus melakukan kunjungan antenatal minimal empat kali selama kehamilannya, yaitu satu kali pada trimester pertama, satu kali pada trimester kedua, dan dua kali pada trimester ketiga. Melalui kunjungan antenatal, ibu hamil diharapkan dapat mengetahui kondisi kehamilannya dan juga janinnya dengan baik. Akan tetapi, terkadang ibu terkendala beberapa hal, sehingga tidak rutin melakukan kunjungan antenatal (Aryastami \& Tarigan, 2012).

Melalui kelas prenatal, ibu hamil dapat melakukan sharing dan diskusi dengan sesama ibu hamil lainnya, sehingga ibu akan lebih paham dengan kondisi kehamilannya (Mediarti et al., 2014). Kelas prenatal memiliki manfaat yang sangat penting bagi ibu hamil. Karena dalam pelaksanaan kelas prenatal, ibu akan diberi penyuluhan kesehatan tentang proses kehamilan, persalinan, nifas, serta bayinya nanti ketika lahir, sehingga ibu hamil dapat mengetahui kondisi diri dan janinnya, yang berdampak pada pengurangan kecemasan. Jumlah ibu hamil yang mengikuti kegiatan $100 \%$ hadir dan kecemasan berkurang sebesar 6,85\%.

\section{KESIMPULAN}

Kelas prenatal pada ibu hamil ini dilaksanakan bertujuan untuk mengurangi kecemasan ibu hamil, terutama ibu 
hamil trimester III, yang notabene sering menghadapi kecemasan menjelang persalinan. Pelaksanaan kegiatan yang dilaksanakan dalam waktu yang singkat sangatlah terbatas. Kegiatan kelas prenatal juga harus menunggu ibu setelah pulang bekerja, sehingga waktu mulai pelaksanaan sedikit mundur dari yang direncanakan. Supaya keberlanjutan transfer IPTEK tetap berjalan, ibu hamil akan menyampaikan materi-materi dan mengajarkan cara yang telah disampaikan kepada ibuibu hamil yang lainnya di wilayah Puskesmas Bangetayu Kota Semarang danjika ibu bekerja, juga akan menyampaikan di kantor tempat mereka bekerja. Saran yang dapat diberikan bagi Puskesmas Bangetayu Kota Semarang adalah kelas prenatal sangat bermanfaat bagi ibu hamil dan keluarganya, sehingga diharapkan bagi Puskesmas dapat memfasilitasi kegiatan tersebut secara berkelanjutan dan bagi ibu hamil adalah ibu hamil diharapkan dapat mengikuti kegiatan kelas prenatal secara aktif.

\section{UCAPAN TERIMA KASIH}

Kami sampaikan terima kasih yang sebesar-besarnya kepada Ir. Prabowo Setiyawan, MT., PhD. selaku Rektor Universitas Islam Sultan Agung Semarang yang telah membiayai kegiatan pengabdian masyarakat ini, Dr., dr. Setyo Trisnadi, SH., Sp. KF. selaku Dekan Fakultas Kedokteran Unissula, dr. Suryanto Setyo Priyadi selaku Kepala Puskesmas Bangetayu Kota Semarang, Bidan Esti Wijayanti, Am. Keb. Selaku bidan Pembina di Puskesmas Bangetayu Kota Semarang, Rekan dosen dan mahasiswa yang telah membantu dalam kegiatan pengabdian masyarakat ini, Serta semua pihak yang tidak bisa kami sebutkan satu persatu.

\section{REFERENSI}

Andriani, Y., Respati, S.H., Astirin, O.P. 2016. Effectiveness of Pregnant Woman Class in The
Prevention of Pregnancy Anemia in Banyuwangi, East Java. Journal of Maternal and Child Health. 1(4):230-241. https://doi.org/10.26911/thejmch.2016.01.04. 04

Aryastami, N.K., Tarigan, I.U. 2012. Perilaku Ibu Hamil Dalam Memeriksakan Kehamilan Trimester Pertama Di Puskesmas Pasanggrahan, Jakarta Selatan. Buletin Penelitian Sistem Kesehatan. 15(1):11-19.

Astuti, A.B., Santosa, S.W., Utami, M.S. 2000. Hubungan Antara Dukungan Keluarga Dengan Penyesuaian Diri Perempuan Pada Kehamilan Pertama. Jurnal Psikologi. 27(2):8495. https://doi.org/10.22146/jpsi.7001

Dwijayanti, P. 2013. Analisis Implementasi Program Perencanaan Persalinan Dan Pencegahan Komplikasi (P4K) Oleh Bidan Desa Di Kabupaten Demak. Jurnal Kesehatan Masyarakat. 2(1):1-11.

Ira, Sabilu, Y., Rasma. 2016. Pemanfaatan Antenatal Care (ANC) Oleh Ibu Hamil Pada Masyarakat Desa Mokupa Kecamatan Lambandia Kabupaten Kolaka Timur Tahun 2015. JIMKesmas (Jurnal Ilmiah Mahasiswa Kesehatan Masyarakat). 1(3):18.

Machmudah, Khayati, N., Widodo, S. 2018. Ipteks bagi Masyarakat (IbM): Pembentukan Kelompok Ibu Hamil Di Desa Kangkung Mranggen Demak. In Seminar Nasional Pendidikan Sains dan Teknologi. Semarang: Universitas Muhammadiyah Semarang, 6 Oktober 2018, 1-6.

Mbuagbaw, L., Medley, N., Darzi, A.J., Richardson, M., Garga, K.H., Ongolo-Zogo, P. 2015. Health system and community level interventions for improving antenatal care coverage and health outcomes. The Cochrane Database of Systematic Reviews.

12:1-157. https://dx.doi.org/10.1002/14651858.CD010 994.pub2

Mediarti, D., Sulaiman, Rosnani, Jawiah. 2014. Pengaruh Yoga Antenatal Terhadap Pengurangan Keluhan Ibu Hamil Trimester III. Jurnal Kedokteran dan Kesehatan: Publikasi Ilmiah Fakultas Kedokteran Universitas Sriwijaya. 1(1):47-53. 
Sasnitiari, N.N., Puspitasari, D.A. 2017. Hubungan Keikutsertaan Ibu Dalam Kelas Ibu Hamil Dengan Pengetahuan Dan Sikap Terhadap Tanda Bahaya Dalam Kehamilan Di Kota Bogor. Jurnal Kesehatan Reproduksi. 8(2):175-185. http://dx.doi.org/10.22435/kespro.v8i2.6424. 175-185

Schott, J.P. 2008. Kelas Antenatal. Jakarta: EGC.

Siwi, Y., Palupi, R. 2018. Analisis Kepatuhan Kunjungan Antenatal Care terhadap Sikap dalam Deteksi Dini Komplikasi Kehamilan pada Ibu Hamil di Wilayah Kerja Puskesmas Munjungan Kecamatan Munjungan Kabupaten Trenggalek. Journal for Quality in Women's Health. 1(1):1-12.

Syafrudin, D. 2011. Untaian Materi Penyuluhan KIA (Kesehatan Ibu dan Anak). Jakarta: Trans Info Media.

Winarni. 2014. Kepuasan Ibu Hamil Terhadap Pelayanan Antenatal Care (ANC) oleh Bidan di Wilayah Kerja Puskesmas Ngoresan. Gaster. 11(2):69-79. 